\title{
FAMILY OF PEOPLE WITH A MENTAL DISORDER AND NEEDS IN PSYCHIATRIC CARE ${ }^{1}$
}

\author{
Jacqueline Botura Bessa², Maria Angélica Pagliarini Waidman ${ }^{3}$
}

\begin{abstract}
${ }^{1}$ Extracted from the dissertation - Cuidado de enfermagem sistematizado à família da pessoa com transtorno mental no paradigma da desinstitucionalização, presented to the Nursing Graduate Program at State University of Maringá (UEM) in 2011, as part of the research project - A trajetória do portador de transtorno mental egresso de emergência psiquiátrica: construindo ações de enfermagem, with financial support from the National Council for Technological and Scientific Development - CNPq.

2 Master in Nursing. Family Health Strategy Nurse in Maringá. Paraná, Brazil. E-mail: jakkelyne@msn.com

${ }^{3}$ Ph.D. in Nursing Philosophy. Professor of the Nursing Graduate Program at UEM. Paraná, Brazil. E-mail: angelicawaidman@ hotmail.com
\end{abstract}

\begin{abstract}
We aimed to learn about the needs of the family which provides care to a person with a mental disorder in the current model of health care. This is a qualitative study conducted in the municipalities of three regional health units in the state of Paraná, using data collection with thirty-two families. Data were analyzed by means of indicators. The results show gaps in the mental health services in relation to the care provided to people with a mental illness and their families with regard to the need for: adaptation after diagnosis of the pathology, family counseling, treatment compliance, hospitalization, financial assistance, transportation assistance, reintegration into society, inclusion in outpatient services after hospitalization, and the bond between professionals and people assisted. We conclude that these requirements need to be explored by mental health network professionals as to the possibility and implementation of deinstitutionalized, integral and decisive assistance to the person with a mental illness and his/her family.
\end{abstract}

DESCRIPTORS: Mental health. Deinstitutionalization. Community health service. Family nursing.

\section{FAMÍLIA DA PESSOA COM TRANSTORNO MENTAL E SUAS NECESSIDADES NA ASSISTÊNCIA PSIQUIÁTRICA}

\begin{abstract}
RESUMO: Objetivou-se conhecer as necessidades da família cuidadora de uma pessoa com transtorno mental no atual modelo de atenção em saúde. Trata-se de um estudo qualitativo, realizado em municípios de três regionais de saúde do Estado do Paraná, empregando-se a coleta de dados com trinta e duas famílias. Os dados foram analisados por meio de indicadores. Os resultados apontam lacunas nos serviços da rede de saúde mental em relação aos cuidados às pessoas com transtorno mental e seus familiares no que diz respeito à necessidade de: adaptação após o diagnóstico da patologia; orientação familiar; adesão ao tratamento; internação; auxílio financeiro; assistência para transporte, reinserção na sociedade; inclusão nos serviços extra-hospitalares após internação; e vínculo entre profissional e pessoa assistida. Conclui-se que estas necessidades precisam ser exploradas pelos profissionais da rede em saúde mental para possibilidade e concretização de uma assistência desinstitucionalizada, integral e resolutiva à pessoa com transtorno mental e sua família.
\end{abstract}

DESCRITORES: Saúde mental. Desinstitucionalização. Serviços de saúde comunitária. Enfermagem familiar.

\section{FAMILIA DE LA PERSONA CON TRASTORNO MENTAL Y SUS NECESIDADES EN LA ASISTENCIA PSIQUIÁTRICA}

RESUMEN: Se tuvo por objetivo conocer las necesidades de la familia cuidadora de una persona con trastorno mental en el actual modelo de atención en la salud. Se trata de un estudio cualitativo, realizado en municipios de tres regiones de salud del Estado de Paraná, empleando el recogimiento de datos de treinta y dos familias. Los datos fueron analizados por meio de indicadores. Los resultados apuntan carencias en los servicios de la red de salud mental en relación a los cuidados a las personas con trastorno mental y sus familiares en lo que concierne la necesidad de: adaptación tras el diagnostico de la patología; orientación familiar; adhesión al tratamiento; ingreso; auxilio financiero; asistencia para transporte; reinserción en la sociedad; inclusión en los servicios extra hospitalarios tras el ingreso y el vínculo entre el profesional y la persona asistida. Por lo tanto llegamos a la conclusión de que estas necesidades necesitan ser exploradas por los profesionales de la red en salud mental para la posibilidad y la concretización de una asistencia no institucionalizada, integral y resolutiva a la persona con trastorno mental y a su familia.

DESCRIPTORES: Salud mental. Desinstitucionalización. Servicios de salud comunitaria. Enfermería familiar. 


\section{INTRODUCTION}

From the psychiatric reform in Brazil, which started in the 1970s, deinstitutionalization is no longer restricted to the simple substitution of treatment models within the hospital; it also involves social, cultural and paradigmatic issues. There is a shift from traditional psychiatric practices to care practices carried out in the community and, more specifically, with the family. ${ }^{1}$

Due to the psychiatric reform there emerges the process of reflection and transformation at the different care, cultural, political, economic and conceptual levels, which, for more than three decades, have been in a growing movement to demystify the stigma of mental illness, and especially to ensure the right of citizenship of these people, so that they can live better in their environment. ${ }^{2}$

Despite several efforts on the part of society for several decades, one of the things that contributed to this paradigm change was the adjustment in mental health legislation, started by ministerial decrees and leveraged by Law 10,216 of 2001. This law was an important landmark for the change in health care institutions, especially in the way of valorizing external actions and psychosocial context, involving mainly the family in the treatment. The family, which was previously taken away from the sick person on the grounds that it could be the source of occasional mental disorder, now has the proposal of deinstitutionalization, assuming the role of main player in care.

The family has been seen as an ally in the process of care for people with mental disorders, but in certain situations, professionals need to offer such a family conditions to keep the household healthy, caring for the person without worsening his/her health condition and that of his/her family as a whole. For this, professional services have become necessary with an adequate care proposal. ${ }^{3}$

In Paraná, Decree n.3,088/2011 established the Psychosocial Care Network in the scope of the Unified Health System (SUS, as per its acronym in Portuguese). The network consists of the following services: Primary Health Care, Specialized Psychosocial Care, Urgent and Emergency Care, Temporary Residential Care, Hospital Care, Deinstitutionalization Strategies and Psychosocial Rehabilitation. The work of the network aims at broadening access to psychosocial care of the general population, promoting the bonding of people with mental disorders and their families with the places of care and ensuring the coordina- tion and integration of points of attention of health networks within the territory, qualifying care by means of acceptance and continuous monitoring. ${ }^{4}$

Nevertheless, it is noticeable that for the consolidation and deinstitutionalization of networking it is not enough simply to replace hospitals with community services; it is also necessary that professionals work, guided by the formulation of deinstitutionalization, so that they are not only transferred into the workplace in psychiatry in which care, in spite of not being rendered at an asylum-type unit, ends up by following the same reasoning.

Under this concept, it is interesting to redeem the meaning of deinstitutionalization as deconstruction of internal walls. We all can liberate ourselves from our strong ties, throw out our fixed identity and move toward our own enrichment and enrichment in the world. The deinstitutionalization of psychiatric hospital inmates and the deconstruction of the asylum-type unit go through a deinstitutionalization of ourselves. ${ }^{5}$

From the issue presented, this study aims to understand the needs of the family that provides care to a person with a mental disorder in the current model of mental health care.

\section{METHOD}

Qualitative approach research, which involves immersion of the investigator into the field of research, is considered as a social scenario, in which the studied phenomenon takes place, and the whole set of elements that form it are in turn formed by it. ${ }^{6}$

The study was conducted in municipalities belonging to three regional health units of Paraná: the 11th Regional Health Unit - Campo Mourão Regional Unit, the 13th Regional Health - Regional Unit of Cianorte, and the 15th Regional Health Unit - Regional Unit of Maringá. Participants were families of people with mental disorders who were attended by the Psychiatric Emergency Room of the Municipal Hospital of Maringá (HMM) in 2008. This is a benchmark service in psychiatry for 67 municipalities from the three regional health units and operates from services to urgent psychiatry, subsequently providing referral to network services, such as: Primary Health Care, Psychosocial Care Centers, Therapeutic Residences, Center for Mental Health Out-Patient/Integrated Clinics and Psychiatric Hospital. 
As a criterion for the selection of families, the database with the monthly total of 2008 was analyzed, which contained records of 4,709 patients who went through the emergency room of the general hospital in the year. The data were classified by diagnosis (alcoholism, depression, drug addiction, schizophrenia, mania, organic problems and others). We excluded the data for diagnoses of alcoholism, drug addiction, organic and other problems (2,947 records), keeping those of depression, schizophrenia and mania, resulting in 1,762 records.

Some patients were not hospitalized and were referred to other services. We decided to select only those who remained hospitalized at the psychiatric emergency room, resulting in 606 records. The duplicate records of patients admitted more than once per year were excluded, resulting in 526 records, of which 428 belonged to the municipalities of the 15th Regional Unit, 64 people to the 11th Regional Unit and 33 to the 13th Regional Unit.

We applied the data collection technique in thirty-two households, the choice of families being made randomly, as per the order of records in the database obtained from the psychiatric emergency room, taking into account the acceptance and availability of the family for the interview.

Oral history was used as the data collection technique, which allows subjective information on the subject and thus makes the method more accurate. The objective when we use oral history, according to this proposal, is the use of interviews such as an operational mechanism capable of guiding the research in the path of pre-established results. $^{7}$

After obtaining the address of the families, contact by phone was made and a home visit was scheduled for clarification of the research. Data were collected at home, in the period May 2009 to March 2010. The choice of the home was made because this environment was believed to retain reality and history, and that the family is capable of remembering the details that enrich data collection. The interviews were recorded and later transcribed.

All collaborators responded to a single question: say what you remember about your family member's illness, from the first episode of the disease until the present day. It was intended that the family history of the disease included recalling its impact on the family, the course of treatment, hospital care and outpatient settings, acceptance of the disease and of the person with the mental illness in the family and community.

Thirty two interviews were collected and analyzed, namely: eight families belonging to the 11th Regional Health Unit, twelve to the 13th Regional Health Unit and twelve, to the 15th Regional Health Unit. The number of interviews was limited to data saturation and the achievement of results. In all, the study involved thirty-two families, but forty-six people collaborated with this research because some families had more than one person as a respondent, namely: F2, two respondents; F3, two; F4, two; F6, three; F8, three; F12, two; F19, two; F20, two; F23, two; F29, three, and F31, two respondents.

Data were analyzed in light of the methodology $\mathrm{y}^{6}$ advocating the production of indicators, which occurs through indirect or omitted information in the course of the research, namely the formulation of these indicators is not direct; it is a set of expressions with the same meaning and derived from different sources of information, which is built by the author's interpretation. Thus, when analyzing the data, the indicators of the study reached, firstly, performing successive readings of the interviews to operationalize and systematize data; then the narratives of different sources, which would meet the objectives of the study, were underlined and organized as per the sum of expressions with the same meaning to codify them and, finally, interpretation of the information omitted was made in the research analysis.

In developing the study, rules established by Resolution 196/96 of the National Health Council were in compliance with, and the study design was approved by the Standing Committee on Ethics in Human Research of the State University of Maringá, by Decree n. 509/2009.

To ensure anonymity, the research collaborators were named by letters and Arabic numerals. To designate the family interviewed the letter " $\mathrm{F}$ " was used followed by numbers according to the order of the interviews.

\section{RESULTS AND DISCUSSION}

The careful reading of the history of the person with the mental disorder, from the pathological diagnosis to the present day, enabled us to identify what the family that lives with a person with a mental disorder needs in the current model 
of health care, revealing care needs for the family and the patient. The following order is the compilation of narratives in the form of indicators, for better understanding and discussion of findings.

\section{Need to adapt the home routine after the diagnosis of mental disorder}

Families who care for people with mental disorders reported that everyday situations are changed with the advent of the disease, which causes, for instance, changes in sleep routine, on job losses and to the financial situation, the need to care for the family member (as to the administration of the medication and body hygiene) and physical and psychological overburden. In addition, the family has to live with situations such as fear and anxiety due to the possibility of a crisis, cannot leave the patient alone, suffer verbal and physical aggression, deal with material losses and have to move to the inpatient unit. These changes cause hardship to the family, especially during the adaptive period due to lack of preparation and guidance regarding mental illness and healthcare for the sick family member. These distressing situations can be observed in the statements: [...] I had to wash him/her, just like I do with his/her father [...] had to feed him/her [...] (F1), when he/she is living with me I am nervous all the time [...] and when he/she is away, I think: 'when he/she is away, I am not so stressed out.' But I do not sleep, thinking: 'Is he/she cold, what is he/she doing? (F9), this time that he/she was hospitalized in the psychiatric clinic, when he/she came back, we had a family party, and at this party, out of nowhere, he/ she managed to pick a fight. People wanted to lynch him, hit his/her sister, nephew hit, and hence, not to be caught there, he/she left by car, speeding and wrecking the car; since then [sigh and anguished look on the face] I have been taking him/her to the doctor (F13); we would worry about a gas bottle, as well as with all those things inside a house [...]. At the time he/she became aggressive, this went on and on until he/she could no longer work; he/she would go and returned, until he lost everything he had. He/she would lock himself/herself, cover up, the whole head would be covered and we always insisted, urging him/her, and we did not know, and every time I would talk to him/ her, he/she covered his/her head and locked himself/ herself up in the room and began to get nervous, and we kept challenging him/her, challenging (F24).

Of all the situations mentioned above we come to the conclusion that one must incorporate the disease into everyday life, using adaptive re- sources, such as identifying a caregiver, dealing with objective and subjective burdens of having a family member afflicted by mental illness, stigma and resulting feelings. ${ }^{8}$ After the mental disorder diagnosis, the family goes through an adaptation period, which requires changes in home routine and in the relationship between their family members with a view to better living.

It is noticed that in the adaptation phase the family changes its life routine, having to refrain from regular activities in order to take care of the sick family member. With this change one sees the lack of preparation to deal with new situations, and this is the time when professional support from the network of mental health services is needed; however, what is observed in most cases is an adaptation without this support, and coping with the difficulties through family practice, which results in the family members' physical overburden and psychic anguish.

\section{Need for family counseling in relation to the crisis and knowledge of mental disorder}

As a result of the need to adapt to new family environmental conditions, with changes in the way of living, collaborators display another indicator of mental health care, which is the need to know the pathology (diagnosis, cause, treatment and prognosis) and learn about the approach of their family member toward crisis episodes; however, lack of guidance was put forward as a difficult daily reality to be coped with, especially in handling the family with regard to the services. My daughter said: 'oh mom, you seek medical care, we want to know why this girl is that way, want to learn about this disease, because until now she had been undergoing treatment and we knew nothing' (F14); sometimes, if there were somebody, at the beginning of the treatment, who would come to us and say: 'look, it's a problem, it is a disease that has no cure. You'll have to deal with it, you will have to have a follow-up', maybe it would not have reached this point. There's no way of knowing $100 \%$ if that's what happened or not. There is no answer, we have a lot of suppositions, but no answer, no [sad look, showing disenchantment with the situation, grimaces, frowns - notes taken from a field diary - January 2011] (F28).

It can be seen in the statement and expression of collaborators that they do not recognize positively the health service professionals that have cared for them at the beginning of treatment and do now. They seem not to have been 
oriented and/or informed about the disease and its treatment, which leads us to understand that often network professionals are unaware of the mental health disorder and how to deal with it. Thus, it becomes difficult to serve the family of co-participants in the care process, since, for the person with a mental illness to remain longer at home, it takes knowledge, commitment and family involvement in treatment.

One study noted the need to provide better guidance to family members on how to deal with the problematic behavior of patients and inform them that the presence of some attitudes, such as agitation, self/hetero aggressions and night disturbance, may suggest the need for adjustment in the patients' medication, with consequent reduction in family burden. ${ }^{9}$ On the other hand, to readjust the medication, one needs to comply with the treatment and this, in most families, is not achieved.

It is noted in the statement of F14 a reference to the physician as a symbol of medical assistance, suggesting a great appreciation for this professional in the treatment of mental health today, but we must remember that in this new paradigm, the proposed treatment is multidisciplinary and intersectorial and may not be centered on a single scientific area. We must leave behind the thought of medication and invest in therapeutic interventions, which also include nursing. Many nursing professionals do not recognize their role in caring for people with mental illness, often getting assistance focused on medical knowledge.

Today, when we think about treatment compliance, it is believed in compliance for various types of therapy involving several specialties, such as occupational psychotherapy, people/nurse therapy relationship, participation in outpatient services and others. Families need to know these new ways of treating mental disorders, and for that, guidance is necessary in the work of professionals that make up the network of mental health services.

\section{Need for the family to help the family member comply with the pharmacological treatment}

Non-compliance to drug treatment was referenced as hampering family care with mental disorder, since lack (or misuse) of drugs gives rise to crises and problems arising from it, generating conflicts in the family: before he was hospitalized, I went to the health station and said he was depressed; he took the medicine for depression that he has been taking to-date, which is nortriptyline. Then he thought he had improved and stopped taking the medicine out of his own judgment. That's when the crisis came with all its might; he went into depression and became psychotic. They started new medication; in addition to depression, for psychosis... [at this time the collaborator lowers her head and shows a sad face, as if she felt helpless in the face of the situation] (F21).

Most collaborators mention trouble convincing their family member to comply with treatment and often stop using the medication once symptoms disappear or when they leave the hospital. Thus, it is believed that the lack of clarification about the importance of not abandoning the treatment, to avoid the emergence of other crises, as well as keeping a life less unstable as to mental disorder, is a gap that still deserves to be better worked by health care professionals.

It is important to remember that because mental disorder is an illness that leaves no visible marks on the body and cannot be proven by tests (laboratory, EEG, or other), the person and his/ her family members have difficulty accepting the disease and its etiology, which makes it difficult to comply with pharmacological treatment. So it takes the commitment of health professionals to make sick people and their families understand how mental illness occurs and how to prevent its recurrence.

After a study of integrative review, ${ }^{10}$ the authors showed that, due to the high number of therapeutic dropouts, it would be interesting if the places that provide psychological treatment and especially the local community care training centers developed actions aimed at prevention and non use of medication or its correct use. This study did not identify prevention activities toward abandonment of drug treatment in services that the family went through; thus it is deemed necessary to fill this gap for a greater completeness of care.

Professionals need to recognize the needs of professional care to people with a mental illness and their families in mental health care. For such, it is important to have systematic services of the cities studied, because the family needs support to be a protagonist in care, as recommended by the paradigm; otherwise, it becomes vulnerable to physical and psychological illness. 


\section{Need for hospitalization in cases of crisis}

In the process of restructuring mental health care, psychiatric hospitals gradually stop constituting the main base of the health care system, giving way to a network of outpatient services of increasing complexity. The psychiatric emergencies in general hospitals represent a breakthrough in the search for comprehensive care for patients with mental disorders in Brazil and a viable replacement of psychiatric hospitals, offering a short-term treatment without isolation of people with mental illness, and especially with no abusive practices. ${ }^{11}$

Despite the aforementioned proposal, the long-term hospitalization was identified by the collaborators of the research: the hospital keeps her for one, two, three years, because this is a long treatment, and here at home there's no way for us to do it, no one can stay, we cannot afford having someone with her 24 hours, there's no way (F16); surely, she needed hospitalization because there in the hospital, there is a psychologist, the medicines are provided at the right time, people talk to her, there are other people with similar problems there, sometimes with very few differences in the disease, and the patient, when hospitalized, naturally improves; it is better than staying at home. The family, how well they care for, cannot provide the same treatment as the hospital can. And there the medication is administered at the right time, there is medical and nursing monitoring, everything. From the psychologist (F32).

It appears that families still turn to hospitals for treatment of the person bearing mental disorders, but this statement contradicts what is advocated by the deinstitutionalized attention model, whereby the ideal situation would be to be hospitalized for a short period of time in general hospital beds.

In this sense, we see that the great challenge is to build a network of alternatives to psychiatric hospitalization that meet the needs of patients that are being deinstitutionalized. Political investment and increasing application of resources in the provision of effective therapeutic outpatient services are of the essence and must be defined. If this is not done, the result is the phenomenon that has been studied since the 1960s, called revolving door, which is characterized by recurring hospitalizations, since, if there are no alternative services, the family and the individuals with psychiatric disorders might continue to see full hospitalization as the main, if not the only, possibility of treatment. ${ }^{12}$
Often, families claim the need for prolonged hospitalization, as stated in the speech of F16. This is due to the difficulty that the family finds in caring for the patient and the lack of preparation and knowledge as to handling a moment of crisis. Despite pointing out this need, the family itself recognizes that the sick family member returns home in the same condition in which he left, that is, they see no results from this type of treatment. This confirms the lack of deinstitutionalized network in mental health care, because even if it there were, in the municipalities surveyed, where the basic units of local health care are located and constitute this complex network, it is observed that these are not developing any actions with regard to the care of the person with the mental disorder and his/her family in the community, which leads us to question the role of primary health care as a service included in the deinstitutionalized network.

Psychiatric disorders are characterized by their chronicity, and living in a closed environment for long periods cannot be an alternative to mental health, but many families do not know and/ or do not recognize the forms of treatment that provide better monitoring and prognosis of the family member's disease. There are families that prioritize service based on the hospital, and there are those that designate their own family unit as the main link in the care of people with a mental disorder. Therefore, one can infer that some families realize their importance for the better prognosis of the family member, just as there are those that still see hospitalization as a protection for their sick relative or a way to not have conflicts at home.

From the foregoing, it appears that the professionals are not engaged in offering care that helps a family take care of the sick person at home, which shows that there are restrictions on outpatient services and also deinstitutionalization while deconstructing the internal barriers of the professionals. This way, one cannot blame the family for acting improperly, it is necessary that the professional, through his/her practice, watch out for this new reality and make interventions when necessary, providing adequate care and comply with the recommendations.

\section{Need for financial resources: aid, cash, or claiming sick or retirement pay}

When they live in municipalities that depend on the services installed in the regional area of a 
city, families comment that in addition to transportation, they must have financial resources for this purpose, because relocation away from their home often affects their employment.

Many families receive financial aid when one of their members suffers a mental disorder, but claim that this benefit does not meet all the demands of the family, such as buying medicines, replacement of household supplies (due to losses in times of crisis), family income impaired in the face of the need to be a caregiver - who quite often must quit their paid job in addition to the difficulty of inserting the person with the mental disorder into the labor market. One day I told him: Doctor, the medicine is too expensive. He gave me the paperwork for me to start the process, I did so, the psychiatrist approved it, the procedure was submitted and resulted in nothing. There is medicine free of charge in the public heal th network; why do they have to ask for a medicine that is expensive if the other one has the same effect? That's what I told you, I have to go there on Monday. if they do not change the drugs, I will have return and buy [...] (F21), he is an excellent master builder, everyone wanted him for construction work, but the way he is, the way I've shown here in the backyard [referring to the house that her husband had not finished building and where he was sitting looking chronically depressive - notes from a field diary], they do not want him working [...]. (F21).

Families point to the difficulties in maintaining a balanced financial situation, as there are many factors involved in this process. Society rejects the service of a person with a mental disorder, since the medication interferes with the worker's productivity; the disease is chronic and there are consequences, causing limitations, in addition the fact that the person with a mental disorder is discouraged and feels powerless in the face of the situation.

The process of reintegration into society that preaches the paradigm of deinstitutionalization has not yet materialized, and the need for measures to improve this situation is visible. One should also take into account that, when one has the symptoms and is found out of control of the treatment, the person has trouble keeping up at work, as highlighted by the speech of F25; therefore, there is the need of removal until the symptoms cease; however, one sees that this distance, which is due to the reduction in the skills and yield at work, brings suffering to the family, out of financial and emotional issues, as reported by F21.
Need for inclusion in outpatient services after returning from the hospital

Families living in cities that have support services outside hospitals, such as the Psychosocial Support Center (CAPS - Centro de Apoio Psicossocial), the Integrated Center for Mental Health (CISAM - Centro Integrado de Saúde Mental), treatment homes and/or self-help groups to exchange experiences, are benefited in caring for the person with a mental disorder; however, the families that need to relocate themselves to render the services previously described face disadvantages that lead to compromising the person's social bonding. Willingly or not, childhood friends grew; today,/she knows people, but/she is isolated, except for the family contact; yet, the contact of father and daughter is divergent; she ends up isolating herself; we wonder if she is not going to participate in this or that; she says she will not; she does participate in CAPS once a week; she likes to go [...], her closest contact, she socializes mostly at CAPS [...]. At CISAM consultation was monthly, even because of the severity of the problem; now the consultation is quarterly. It would be interesting if the interval between visits were lower, but it has CAPS monitoring, and there they see how things are, the way it is, the socializing, if she is more isolated or not (F28); we think that returning to society, in the sense of doing an activity, returning to work, being accepted by other people, having a normal life, would be possible if she took her medicine correctly and had the community's help; I think this would be useful (F1).

Through the statements presented one is able to observe that there are difficulties in implementing the psychiatric reform as it relates to the sociocultural magnitude, highlighting stigma, prejudice and exclusion. In this case, it would be important to invest in the health network, strengthening the bonds of solidarity and identifying potential resources of the territory in the psychosocial rehabilitation process. In this context, it is observed that nurses play a significant role in this process and may act as educators/counselors; however, to work with the community one must know that this happens slowly because it involves culture and rooted (pre)notions, especially those related to the lack of capability and use of the person with the mental disorder.

The participation of the people with a mental illness in care outside the hospital walls favors social relationship and promotes reintegration into society. Some authors, ${ }^{1}$ when one speaks of this theme, state that social reintegration requires 
that professionals in the mental health area relinquish power and control historically delegated to them. They reinforce that these professionals have to give up management and control of the lives of people with mental disorders and seek changes in the notion of the disease, in social reinsertion and how to see them and treat them in our society.

Families reveal the need for their sick family member to reenter into society, in addition to the precision of care in support services outside hospitals, and when observed in this light, we can see improvement in family relationships and less damage compared to those resulting from unsatisfactory treatment in mental health. Nevertheless, people residing in counties that do not have outpatient services have the greatest difficulties in supporting the inclusion of the sick person into society, which shows that primary care, a bond in the network that would function as an extra wall service, does not provide the resources that the family requires.

\section{Need for bonding between professionals and the assisted persons}

Besides the inclusion of the person with a mental disorder in the community services, there must be a bond between him/her, the family and the professional offering service assistance. This is because a relationship of trust in the healthcare can be established, and the family can express its needs, that is, it can be heard in a way that is consistent with the principles of integral human mental health care.

It is known that in order to make an appropriate and healthy family living with a person with a mental illness there must be a specialized service that supports and clarifies their doubts and guides them in their difficulties. In preparing the family and community to welcome the person with a mental illness to return from the psychiatric institution, it is possible that this person and his/ her family lead their lives with quality and without compromising anybody's mental health. ${ }^{13}$

It is necessary for substitute services to assist families, listen attentively to their questions and difficulties about coping with the disease of family member, and help promote the necessary changes that arise in contact with the community where the person is inserted. To reach these goals the bond is needed between the patient and the professional: if he/she took the correct medicine, I think he/she would be fine at home without hospitalization; if he/she had regular doctor's consultations and if assessment were made of the medication; if a diagram was made of the situation and put into practice [...] if they explained: 'look, his/her appetite is worse,' or, 'he/she is very sleepy', side effects, his/her behavior: 'no, look, it's all in line, there's been no problem; that is, there has been no bowel trouble, no urine problem, because the medication attacks several areas! Sometimes there is no problem, at other times, he/she gets sleepy, which is his/her case, makes him/her kind of slow in the situation. I think that's why sometimes he/she stops taking the medication because of sexual performance, and he/ she has a love life. If the family and the patient had a closer follow-up, if, the city would allow it, I think both he/she and we could stay home and be that close, lead a normal life (F6).

Communication by speech represents a comprehensive manner in the sum of all the aforementioned requirements and accurately demonstrates several gaps in mental health services, which sets up the non implementation of an effective job as advocated in the principles of deinstitutionalized health care. It is noted that the family recognizes the importance of time between visits, which when extended, leaves the person unassisted, in addition to which the problems of professionals with regard to charts and the continuity of follow-up, reveal the difficulty of the services in performing referral and counter-referral.

Collaborators refer that it is possible to lead a normal life, provided that care is efficient and decisive. For such, they speak of the need to comply with the treatment, systematic and programmed monitoring, the importance of holistic care on the part of the professional in different areas of and value of guidelines for those who are considered "laymen."

The importance of support services outside the hospital network to create a bond between the professional and the person is evident, so that we can observe that if their needs are met and a prolonged hospitalization of the family member is not required, their monitoring can be performed at home and in community health services. Non-compliance to treatment leads to relapse, requiring return to the hospital, but if there is an accompaniment that is satisfactory and meets the needs already identified by the study, damages decrease and the service becomes full and thus guided by the paradigm of deinstitutionalization; 
however, to reach this result, it is necessary not only to change mental health policy, but also the professionals should try to work with their limitations and get involved in defending assistance outside the hospital.

Recent studies advocate the inclusion of family members in mental health care, but to make this task a reality we must prepare professionals in the area to see relatives as collaborators in care practices dedicated to people with a mental disorder. ${ }^{14-17}$

\section{FINAL CONSIDERATIONS}

From this study, it is clear that mental health care is undergoing a period of transformation of concepts and models of care since with psychiatric reform, care paradigm is based on service outside the hospital, with a focus on social reintegration; however, gaps are noted in the network assistance to the family and people with a mental disease regarding their experience with psychiatric health services.

It was observed that mental health care, as of family needs, can be exploited by professionals who assist and work in the network of health services, as a practice to improve health care. Nursing care under this conjuncture becomes paramount, because this profession is present in most of the services available, but what it is being analyzed is a lack of improvement of this work, which must be decisive and have scientific basis.

The study revealed needs for mental health care that need to be reviewed and studied by researchers, managers and professionals in the area of psychiatry, aiming at strengthening psychiatric treatment, especially with regard to networking. If the health care system and its professionals meet these demands, the person with a mental illness can live in the home environment so as to reduce the caregiver's burden and conflicts that arise in this environment.

To consolidate a comprehensive care and humane network of mental health care as it is recommended by the psychiatric reform, it is crucial that there is financial support for the network of community services in health and systematization of the working process in these services. For such, it is necessary to know the needs of the families that care for the people with a mental illness and seek to solve these challenges based on science, i.e. systematically.

\section{REFERENCES}

1. Gambatto R, Silva ALP. Reforma Psiquiátrica e a reinserção do portador de transtorno mental na família. Psicol Argum. 2006 Abr-Jun; 24(45):25-33.

2. Santos ACCF. Referencial de cuidar em enfermagem psiquiátrica: um processo de reflexão de um grupo de enfermeiras. Esc Anna Nery. 2009 Jan-Mar; 13(1):51-5.

3. Waidman MAP, Rocha AFP, Zambon AR, Radovanovic CAT. Vivenciando problemas de saúde em família: a implementação de uma proposta teórica metodológica de cuidado. Online Braz J Nurs [online]. 2007 [acesso 2011 Jul 17]; 6(0):1-10. Disponível em: http:/ / www.uff.br/objnursing/ index.php/nursing/rt/printerFriendly/648/151

4. Ministério de Estado da Saúde (BR). Portaria GM $n^{\circ}$ 3.088, de 23 de dezembro de 2011: institui a rede de Atenção Psicossocial para pessoas com sofrimento ou transtorno mental e com necessidades decorrentes do uso de crack, álcool e outras drogas, no âmbito do Sistema Único de Saúde. Diário Oficial do Estado do Paraná. 23 dez 2011; Seção 1.

5. Basaglia F. A instituição negada. Rio de Janeiro (RJ): Graal; 1985.

6. Rey FG. Pesquisa qualitativa e subjetividade: os processos de construção da informação. São Paulo (SP): Pioneira Thomson Learning; 2005.

7. Meihy JSB, Holanda F. História oral: como fazer e como pensar. São Paulo (SP): Contexto; 2007.

8. Navarini V, Hirdes A. A família do portador de transtorno mental: identificando recursos adaptativos. Texto Contexto Enferm. 2008 Out-Dez; 17(4):680-8.

9. Barroso SM, Bandeira M, Nascimento E. Sobrecarga de familiares de pacientes psiquiátricos atendidos na rede pública. Rev Psiquiatr Clin. 2007; 34(6):270-7.

10. Benetti SPC, Cunha TRS. Abandono de tratamento psicoterápico: implicações para prática clínica. Arq Bras Psicol. 2008; 60(2):48-59.

11. Silva NG, Oliveira AGB. Interconsulta psiquiátrica e unidades de internação psiquiátrica no Brasil: uma pesquisa bibliográfica. O mundo da saúde. 2010; 34(2):244-51.

12. Parente CJS, Mendes LPF, Souza CNS, Silva DKM, Silva JC, Parente ACBV, Parente ACM. O fenômeno de revolving door em hospitais psiquiátricos de uma capital do nordeste brasileiro. Reme: Rev Min Enferm. 2007 Set-Dez; 11(4):381-86.

13. Waidman MAP, Elsen I, Marcon SS. Possibilidades e limites da teoria de Joyce Travelbee para a construção de uma metodologia de cuidado à família. Rev Eletr Enferm [online]. 2006 [acesso 2011 Abr 12] 8(2):282-91. Disponível em: http://www. fen.ufg.br/revista/revista8_2/v8n2a13.htm

14. Luzio CA, L'Abbate SA. Atenção em saúde mental em municípios de pequeno e médio portes: 
ressonâncias da reforma psiquiátrica. Cienc Saude Colet [online]. 2009 [acesso 2011 Nov 10] 14(1):10516. Disponível em: http://www.scielo.br/pdf/csc/ v8n2/a02v08n2.pdf

15. Waidman MAP, Radovanovic CAT, Scardoelli MGC, Estevam MC, Pini JS, Brischiliari A. Estratégia de cuidado a famílias de portadores de transtornos mentais: experiências de um grupo de pesquisa.
Cienc Cuid Saude. 2009; 8(supl):97-103.

16. O' Doherty YK, Doherty DT. Satisfied carers of persons with enduring mental illness: who and why? Int J Soc Psychiatry. 2009 May; 55(3):257-71.

17. Brischiliari A, Waidman MAP. O portador de transtorno mental e a vida em família. Esc Anna Nery. 2012; 16(1):147-56. 